\title{
Effect of Audit Tenure, Financial Condition, Audit Quality, and Leverage on Going Concern Audit Opinions in the Hospitality, Restaurant, and Tourism Sector Listed on the Indonesia Stock Exchange in 2017-2019
}

\author{
Erin Cecilia Dianto ${ }^{1}$, Rita $^{2}$, Arie Pratania Putri ${ }^{3}$ \\ 1,2,3 Universitas Prima Indonesia, Indonesia \\ Corresponding Author: Arie Pratania Putri
}

\begin{abstract}
The purpose of this study is to determine and examine the effect of audit tenure, financial condition, audit quality, and leverage on going concern audit opinions in the hospitality, restaurant, and tourism sector listed on the Indonesia Stock Exchange in 2017-2019. This research is a quantitative descriptive research. The data used comes from the IDX website www.idx.co.id and meets the requirements. Purposive sampling was used to collect a sample of 11 companies from a population of 35. Data were analyzed using logistic regression analysis. The results show that audit tenure has no significant effect on going concern audit opinions. Financial condition has no significant effect on going concern audit opinions. Audit quality has no significant effect on going concern audit opinions. Leverage has no significant effect on going concern audit opinions.
\end{abstract}

Keywords: Audit Tenure, Financial Condition, Audit Quality, Leverage, Going Concern Audit Opinions

\section{INTRODUCTION}

Auditors are involved in many bankruptcies. Because financial records demonstrate the viability of the company, financial accounts can be impacted by the company's Going Concern Audit Opinion (Fernando and Hadiprajitno, 2015).
The auditor provides a going concern opinion based on the company's Going Concern Audit Opinion. The auditor's assessment of the company's Going Concern Audit Opinion is a going concern opinion. This perspective is detrimental to users of financial statements (Astuti and Darsono, 2012). PT Hanson Internasional Tbk is a well-known example (MYRX). The Financial Services Authority (OJK) punished Ernst and Young for not presenting the financial statements of PT Hanson Internasional Tbk (MYRX). So the STTD registered certificate is valid for 1 year. OJK considers this KAP to be in violation due to the incomplete audit of the financial accounts of PT Hanson Internasional Tbk. OJK attributed Rp613 billion to the company's mistakes so that revenue recognition uses the full accrual method so that transactions are worth Rp732 billion. PT Hanson is a vendor for ready-tobuild plots (KAIBA), and financial records do not include PPJB. Many factors have an impact on going concern audit perspective, but the results are inconsistent.

The purpose of this study is to determine and examine the effect of audit tenure, financial condition, audit quality, and leverage on going concern audit opinions in the hospitality, restaurant, and 
Erin Cecilia Dianto et.al. Effect of audit tenure, financial condition, audit quality, and leverage on going concern audit opinions in the hospitality, restaurant, and tourism sector listed on the Indonesia stock exchange in 2017-2019.

tourism sector listed on the Indonesia Stock Exchange in 2017-2019.

\section{LITERATURE REVIEW \\ Going Concern Audit Opinions}

Auditors will provide opinions with paragraphs expressing their doubts or concerns about their survival (Muttaqin and Sudarno, 2012). A negative audit opinion from the auditor is bad news for the company, Sourced from Elmawati and Yuyetta (2014). Nonetheless, the auditor expects the company to resolve the issue and continue normal operations.

\section{Audit Tenure}

Audit tenure is a term of cooperation between KAP and its customers. Long participation reduces auditor independence, so the evaluation is less than optimal (Ulya, 2012). Article 11 of the Indonesian Tenure Audit Regulation stipulates that general audit services on financial statements can only be provided for a maximum of 5 years. However, the auditor may re-audit the client's financial statements after two years.

\section{Financial Condition}

Dewayanto (2011) claims that the company's financial situation reflects the overall financial health. A going concern audit opinion is not possible in both cases. Putrady and Haryanto found that the company was unable to pay expenses due to financial constraints. If this happens, there are more opportunities for a going concern audit opinion.

\section{Audit Quality}

Audit quality as the following audit criteria in order to reveal auditor violations. Auditors must provide excellent audit reports because decision makers depend on them. Competent auditors prefer going concern audit findings when audit service clients experience going concern problems.

\section{Leverage}

Rahayu and Pratiwi (2011) say that the leverage ratio variable shows the company's ability to utilize commitments to obtain financing. They experienced a decrease in their ability to express a going concern audit opinion due to an increase in the leverage ratio.

\section{RESEARCH METHODS}

This research is a quantitative descriptive research. Descriptive research is a type of research that aims to make a systematic, factual and accurate description of the facts and characteristics of the population of a particular area (Pandiangan et al., 2021). Quantitative research is empirical research where the data is in the form of something that can be calculated. Quantitative research pays attention to the collection and analysis of data in numerical form (Pandiangan, 2015).

According to Sugiyono (2016), population is a region generalization consisting of objects or subjects that have certain qualities and characteristics defined by researchers to studied and then draw conclusions. According Pandiangan et al. (2018) in Sugiyono, purposive sampling is the selection of samples based on certain characteristics that are considered to have relevance to the characteristics of the population that have been known previously. Purposive sampling was used to collect a sample of 11 companies from a population of 35.

Library research of reference sources is a form of research that uses library facilities by examining theoretical discussions from various books, articles, and scientific works related to writing (Pandiangan, 2018). The data used comes from the IDX website www.idx.co.id and meets the requirements.

Data were analyzed using logistic regression analysis. The research used multiple linear regression methods with ordinary least square (OLS) to find out how far the influence of independent variables on dependent variable (Tobing et al., 2018). 
Erin Cecilia Dianto et.al. Effect of audit tenure, financial condition, audit quality, and leverage on going concern audit opinions in the hospitality, restaurant, and tourism sector listed on the Indonesia stock exchange in 2017-2019.

RESULT

\section{Coefficient of Determination (R Square)}

Table 1. Coefficient of Determination (R Square)

\begin{tabular}{cccc}
\hline Step & -2 Log Likelihood & Cox \& Snell R Square & Nagelkerke R Square \\
\hline 1 & $20,541^{*}$ &, 110 &, 210
\end{tabular}

From Table 1 it can be seen that the nagelkerke $\mathrm{R}$ square value is 0.210 . Thus, the variability of the dependent variable can be explained by as much as $21 \%$ by the independent variable, while other variables outside the research can explain the remaining $79 \%$.

\section{Hypothesis Test}

Table 2. Logistics Regression Test Results

Table 2. Logistics Regression Test Results
\begin{tabular}{|l|c|c|}
\hline Variable & B & Sig. \\
\hline Audit Tenure & 0.270 & 0.649 \\
\hline Financial Condition & -19.915 & 0.999 \\
\hline Audit Quality & 2.990 & 0.714 \\
\hline Leverage & 0.843 & 0.599 \\
\hline Going Concern Audit Opinions & 3.381 & 0.174 \\
\hline
\end{tabular}

The constant variable has a coefficient of -3.381 in the regression equation. Going concern audit opinions will depreciate 3.381 .

Audit tenure has a coefficient of 0.270 . The audit tenure reduces the company's going concern audit opinioned by $27 \%$. This illustrates the negative orientation of the model. The results show that audit tenure has no significant effect on going concern audit opinions. These results are supported by research by Fahmi (2014) with Kurnia and Mella (2018).

A $100 \%$ increase in the financial condition reduces the company's going concern audit opinions by $19.915 \%$. This illustrates the negative orientation of the model. Financial condition has no significant effect on going concern audit opinions. This result is supported by research by Astuti and Darsono (2012).

The coefficient on the audit quality is 2.990 , which means that for every $100 \%$ increase in the audit quality, the company will receive a 299 percent increase in going concern audit opinions. Audit quality has no significant effect on going concern audit opinions. This result is supported by research by Astuti and Darsono (2012).

Leverage has no significant effect on going concern audit opinions. This result contradicts the research of Altman and McGough (1974).

\section{CONCLUSION AND SUGGESTION}

The results show that audit tenure has no significant effect on going concern audit opinions. Financial condition has no significant effect on going concern audit opinions. Audit quality has no significant effect on going concern audit opinions. Leverage has no significant effect on going concern audit opinions. follows:

Suggestions in this study are as

1. Other factors such as audit delay, opinion shopping, and financial difficulties can have an effect on going concern audit opinions.

2. Apart from hospitality, restaurant, and tourism, further studies are expected.

\section{Acknowledgement: None}

\section{Conflict of Interest: None}

\section{Source of Funding: None}

\section{REFERENCES}

1. Altman, Edward I \& McGough, T. (1974). Evaluation of a Company as a Going Concern. Journal of Accountancy, 50-57.

2. Astuti, Irtani Retno \& Darsono. (2012). Pengaruh Faktor Keuangan Dan Non Keuangan Terhadap Penerimaan Opini Audit Going Concern. Diponegoro Journal of Accounting, 1(2):1-10.

3. Dewayanto, Totok. (2011). Analisis Faktorfaktor yang Mempengaruhi Penerimaan Opini Audit Going Concern pada Perusahaan Manufaktur yang Terdaftar di Bursa Efek Indonesia. Jurnal Fokus Ekonomi, 6(1).

4. Elmawati, Dian \& Yuyetta, Etna Nur Afri. (2014). Pengaruh Reputasi KantorAkuntan Publik (KAP), Audit Tenure, Disclosure Terhadap Penerimaan Opini Audit Going Concern. E-Jurnal Akuntansi, 3(2). 
Erin Cecilia Dianto et.al. Effect of audit tenure, financial condition, audit quality, and leverage on going concern audit opinions in the hospitality, restaurant, and tourism sector listed on the Indonesia stock exchange in 2017-2019.

5. Fahmi, Irham. (2014). Analisis Kinerja Keuangan: Panduan Bagi Akademisi, Manajer, dan Investor untuk Menilai dan Menganalisis Bisnis dari Aspek Keuangan. Bandung: Alfabeta.

6. Fernando, R. \& Hadiprajitno, P. B. (2015). Analisis Faktor-faktor yang Berpengaruh Terhadap Penerimaan Opini Audit Going Concern. Diponegoro Journal of Accounting, 4(3), 1-10.

7. Kurnia,. P. \& Mella,. N. F. (2018). Opini Audit Going Concern: Kajian Berdasar Kualitas Audit, Kondisi Keuangan, Audit Tenure, Ukuran Perusahaan, Pertumbuhan Perusahaan dan Opini Audit Tahun Sebelumnya pada Perusahaan yang Mengalami Financial Distress pada Perusahaan Manufaktur (Studi pada Perusahaan Manufaktur yang Terdaftar di Bursa Efek Indonesia Tahun 2010-2015). Jurnal Riset Akuntansi dan Keuangan, 6(1)

8. Muttaqin, A. N. \& Sudarno, S. (2011). Analisis Pengaruh Rasio Keuangan dan Faktor Non Keuangan Terhadap Penerimaan Opini Audit Going Concern (Studi Empiris pada Perusahaan Manufaktur di BEI Tahun 2008-2010). Jurnal Akuntansi dan Auditing, 7(2):164-181.

https://doi.org/10.14710/jaa.7.2.164-181.

9. Pandiangan, Saut Maruli Tua. (2015). Analisis Lama Mencari Kerja Bagi Tenaga Kerja Terdidik di Kota Medan. Skripsi. Medan: Fakultas Ekonomi dan Bisnis, Program Studi Ekonomi Pembangunan, Universitas Sumatera Utara. https://www.academia.edu/52494724/Analis is_Lama_Mencari_Kerja_Bagi_Tenaga_Ker ja_Terdidik_di_Kota_Medan.

10. Pandiangan, Saut Maruli Tua. (2018). Analisis Faktor-faktor yang Mempengaruhi Penawaran Tenaga Kerja Lanjut Usia di Kota Medan. Tesis. Medan: Fakultas Ekonomi dan Bisnis, Program Studi Ilmu Ekonomi, Universitas Sumatera Utara. http://repositori.usu.ac.id/bitstream/handle/1 23456789/10033/167018013.pdf?sequence= 1 \&isAllowed $=\mathrm{y}$.

11. Pandiangan, Saut Maruli Tua, Rujiman, Rahmanta, Tanjung, Indra I., Darus,
Muhammad Dhio, \& Ismawan, Agus. (2018). An Analysis on the Factors which Influence Offering the Elderly as Workers in Medan. IOSR Journal of Humanities and Social Science (IOSR-JHSS), 23(10), 76-79. DOI: 10.9790/0837-2310087679.

12. Pandiangan, Saut Maruli Tua, Resmawa, Ira Ningrum, Simanjuntak, Owen De Pinto, Sitompul, Pretty Naomi, \& Jefri, Riny. (2021). Effect of E-Satisfaction on Repurchase Intention in Shopee User Students. Budapest International Research and Critics Institute-Journal, 4(4), 77857791.

DOI: https://doi.org/10.33258/birci.v4i4.2697.

13. Rahayu, A. W., \& Pratiwi, C. W. (2011). Pengaruh Opini Audit Tahun Sebelumnya, Pertumbuhan Perusahaan, Leverage dan Reputasi Auditor Terhadap Penerimaan Opini Going Concern. Proceeding PESAT (Psikologi, Ekonomi, Sastra, Arsitektur \& Sipil), 98-104.

14. Sugiyono. (2016). Metode Penelitian Administratif. Bandung: Alfabeta.

15. Tobing, Murniati, Afifuddin, Sya'ad, Rahmanta, Huber, Sandra Rouli, Pandiangan, Saut Maruli Tua, \& Muda, Iskandar. (2018). An Analysis on the Factors Which Influence the Earnings of Micro and Small Business: Case at Blacksmith Metal Industry. Academic Journal of Economic Studies, 5(1), 17-23. https://www.ceeol.com/search/articledetail?id=754945.

16. Ulya, Alfaizatul. (2012). Opini Audit Going Concern: Analisis Berdasarkan Faktor Keuangan dan Non Keuangan. Accounting Analysis Journal, 1(1).

How to cite this article: Dianto EC, Rita, Putri AP. Effect of audit tenure, financial condition, audit quality, and leverage on going concern audit opinions in the hospitality, restaurant, and tourism sector listed on the Indonesia stock exchange in 2017-2019. International Journal of Research and Review. 2021; 8(11): 171-174. DOI: https://doi.org/10.52403/ijrr.20211123 